\title{
The Hondelange Formation and the sequence stratigraphic model of Belgian Lorraine
}

\author{
Frédéric BOULVAIN ${ }^{1 *} \&$ Isabelle BELANGER ${ }^{2}$
}

\begin{abstract}
1 Pétrologie sédimentaire, Université de Liège, B20, Sart Tilman, B-4000Liège, Belgium; fboulvain@uliege.be. 2 Service géologique de Belgique, 13 rue Jenner, B-1000 Bruxelles, Belgium; isabelle.belanger@naturalsciences.be. * corresponding author
\end{abstract}

\begin{abstract}
A detailed survey of the Sinemurian-Pliensbachian Hondelange Formation in southern Belgium led to propose a new lithostratigraphic status for this unit. Important lateral variations together with a $10^{\circ}$ angular unconformity with respect to underlying formations suggest that the Hondelange Formation is a prominent element of the transgressive prism in Belgian Lorraine. This study also offers a sequence stratigraphic model for this area with precise description and location of transgressive and maximum flooding surfaces. These results are compared with previous models. A comparison of the magnetic susceptibility data (MS) with sequence stratigraphic units shows that no special effect of the system tract nature is observed. Depositional sequences however are characterized by different mean MS values according to their general sedimentary settings.
\end{abstract}

KEYWORDS: Triassic, Jurassic, lithostratigraphy, system tracts, magnetic susceptibility.

\section{Introduction}

This work follows up former papers dedicated to major boreholes in Belgian Lorraine and Grand Duchy of Luxembourg: the Latour borehole (Boulvain \& Monteyne, 1993, revised by Boulvain et al., 1995), the Neulimont, Aubange, Saint-Mard and Toernich boreholes (Boulvain et al., 1995), the Villers-devant-Orval borehole (Boulvain et al., 1996) and more recently, the Bonnert, Haebicht, Grouft, Grund, and Consdorf boreholes (Boulvain et al., 2017). These studies, together with data resulting from the geological mapping project for Wallonia (Belanger et al., 2002; Ghysel et al., 2002; Belanger, 2006 a, b; Ghysel \& Belanger, 2006) led to a synthesis formalized by a new lithostratigraphical scheme for Belgian Lorraine (Boulvain et al., $2001 \mathrm{a}, \mathrm{b}$ ). Besides stratigraphical data, the boreholes survey provided results for petrography, clay mineralogy, palynology and paleontology (Boulvain et al., 2001a; Boulvain et al., 2017).

The purpose of the current work is (1) to suggest a new status for the Hondelange Formation, formerly considered as a member of the Arlon Formation (Boulvain et al., 2001b) and (2) by synthetizing all the information acquired from the boreholes and outcrops, to propose a sequence stratigraphic interpretation for the Triassic and Jurassic of Belgian Lorraine and border areas.

\section{Geological setting}

The studied Triassic to Jurassic successions are confined to the south eastern part of Belgium, i.e. the Belgian Lorraine and to the Guttland region of G.-D. of Luxembourg. The region is characterized by a typical cuesta morphology due to the alternation of soft and hard sediments together with a shallow dip to the south (Lucius, 1952; Maubeuge, 1954).

The oldest formation covering the Ardenne-Eisleck peneplaned basement corresponds to an alluvial system (clays and gravels of the Habay Formation in Belgium, probably younger than the red sandstones and gravels from the Buntsandstein Group in G.-D. of Luxembourg) (Fig. 1). The progressive younging of formations westwards is conspicuous, with the Triassic marine transgression progressing from southeast to northwest. The first marine influence is classically recorded by the Muschelkalk Group in G.-D. of Luxembourg, with dolostones, evaporite-bearing marls and encrinites. However, even earlier marine facies were recently recognized by Dittrich (2017) in the upper Buntsandstein Group. In Belgium, the first marine influence is recorded by the Attert Formation with argillites and dolomitic marls including evaporitic pseudomorphs. The Triassic marine transgression comes to an end with the deposition of littoral sandstones and marls of the Mortinsart Formation which are locally topped by alluvial clay (Argile de Levallois) (Boulvain et al., 2001a).

The development of a shallow epicontinental sea covering the Paris basin (Purser, 1975; Ziegler, 1990) was initiated during the early Jurassic through the transgressive pulse of the Ligurian major sedimentary cycle (de Graciansky et al., 1998). The globally warm climate (e.g. Mouterde et al., 1980; Hallam, 1985; Dera et al., 2011), among other factors, allowed the carbonate factory to start (Pomar \& Hallock, 2008). In the north-eastern part of the basin, carbonate sedimentation is associated with abundant influxes of siliciclastic sediments (Waterlot et al., 1973; Mouterde et al., 1980).

The Hettangian Jamoigne Formation (G.-D. of Luxembourg: Elvange Formation) shows a typical Lorraine facies with alternating marls and fossil-rich bioturbated argillaceous limestones. Above this unit, the Luxembourg Formation is a Hettangian and Sinemurian sandstone deposited in the Belgian Lorraine, in central and southern G.-D. of Luxembourg, north-eastern France and westernmost Germany (Steininger, 1828; Dumont, 1842; Dewalque, 1854). The sandy material was supplied from the German basin to the Paris basin across the Eifel depression (Muller et al., 1973), and deposited as subtidal sandbars in a vast deltaic system (Mertens et al., 1983; Berners, 1983). The lenticular sandy facies shifted gradually from the center of G.-D. of Luxembourg towards the northwest, onto the Ardenne massif. The diachronous pattern from east to west has been precisely determined using biostratigraphical data (Maubeuge, 1965; Guérin-Franiatte \& Muller, 1986; Guérin-Franiatte et al., 1991).

In the central part of the Belgian Lorraine, interdigitations of the marly Lorraine facies (Arlon Formation) with the Luxembourg sandstone defines respectively the Tritte, Strassen, La Posterie marly units and the Metzert, Chevratte, Florenville, Orval, and Virton sandy units (Boulvain et al., 2001b). The SinemurianPliensbachian Hondelange Formation is a mixed facies with marls and bioturbated calcareous sandstone.

Later Pliensbachian and Toarcian formations correspond to fine-grained dark argillites and marls (Ethe, Messancy and Grandcourt formations) alternating with a mixed marl-sandstone unit (Aubange Formation). These formations are locally rich in organic matter, indicating quiet sedimentation conditions on an anoxic sea floor. In G.-D. of Luxembourg, the top of the Toarcian is sandy with ironstone beds (the well-known "Minette" iron ore), which when fully developed is of Aalenian age (Faber et al., 1999; Bintz \& Storoni, 2009). In Belgium, the Aalenian beds were partly eroded during a significant emersion (top of the Ligurian cycle, cf. de Graciansky et al., 1998). The youngest Jurassic strata belong to the Bajocian in both countries. This stage is characterized by the development of a carbonate platform (Boulvain et al., 2017).

\section{Methods}

Petrographic samples for thin sections (500 for the present study) were selected from all facies, even unconsolidated. In that case, samples were indurated with Geofix ${ }^{\circledR}$ resin. All the thin sections are kept at the Laboratoire de Pétrologie sédimentaire in Liège. Magnetic susceptibility (MS) measurements were made on 2089 samples using a KLY-3 Kappabridge device (see Da Silva \& Boulvain, 2006). Three measurements were made on each sample 


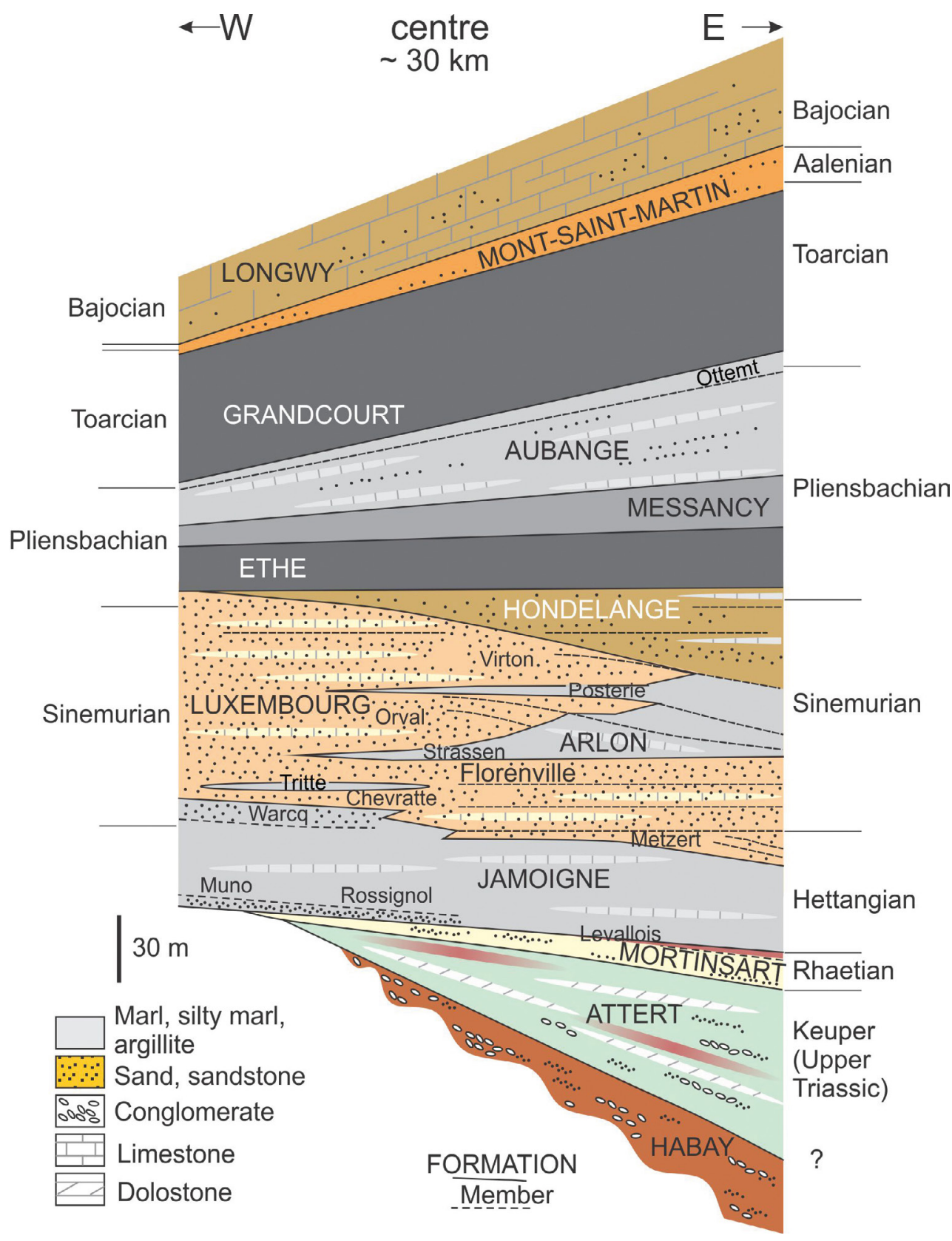

Figure 1. Upgraded stratigraphic scheme for Belgian Lorraine.

weighed with a precision of $0.01 \mathrm{~g}$. Sampling interval varies but is less than $1 \mathrm{~m}$.

Petrography and MS were used in a former study to characterize formations and paleoenvironments (Boulvain et al., 2017). They are also used here to characterize system tracts and depositional sequences.

\section{The Hondelange Formation}

The "Assise de Hondelange" was a long-standing lithostratigraphic unit from the Lower Jurassic succession in Belgian Lorraine, remarkable for its mixed sandy and argillaceous facies (cf. Dormal, 1894; Maubeuge, 1952, 1954). This unit is often transitional with the Virton Member in the eponymous region (Maubeuge, 1954, 1963 ) and these two units were mapped together on the 1/40 000 detailed geological maps (see for example Dormal \& Purves, 1897: Meix-devant-Virton - Virton).

For the Sinemurian-Pliensbachian interval, the new geological maps of Wallonia (Fig. 2) present two synchronous formations distinguished by contrasting lithologies, the Luxembourg Formation with a sandy facies and the Arlon Formation which is argillaceous (Fig. 1). According to the Boulvain et al. (2001b) proposal, the Hondelange unit was included as a member in the uppermost part of the Arlon Formation. However, this relatively simple distinction between Luxembourg and Arlon formations has proven to be less relevant for the Hondelange unit due to its mixed lithology. Moreover, geometrically speaking, an angular unconformity is observed locally at the base of the Hondelange unit. These facts led us to propose to modify the lithostratigraphic status of the Hondelange Member into Hondelange Formation. The following is a summary of the main lithological characteristics of the Hondelange Formation, as observed in the boreholes and during the geological survey of Belgian Lorraine (Belanger et al., 2002; Ghysel et al., 2002; Belanger, 2006 a, b; Ghysel \& Belanger, 2006).

The typical Hondelange facies that can be observed in boreholes and some rare outcrops (Figs 3 and 4) is a grey to yellowish-grey argillaceous calcareous sandstone. Unlike the Luxembourg sandstone, that of Hondelange is poorly sorted with sandy or argillaceous patches and with black millimetric dots of organic matter. Fossils are frequent such as belemnites, bivalves, echinoderms, ammonites. The weathering gives a typical orange color to the Hondelange facies. More precisely, in the Latour borehole (Fig. 4), the Hondelange Formation starts over the yellowish sandstones of the Luxembourg Formation by a grey to brown bioclastic sandy limestone bed (182.8-182.1 m), passing upwards to an alternation of dark grey to brown bioturbated sandy or silty marls and decimeter-thick pale grey bioturbated or 


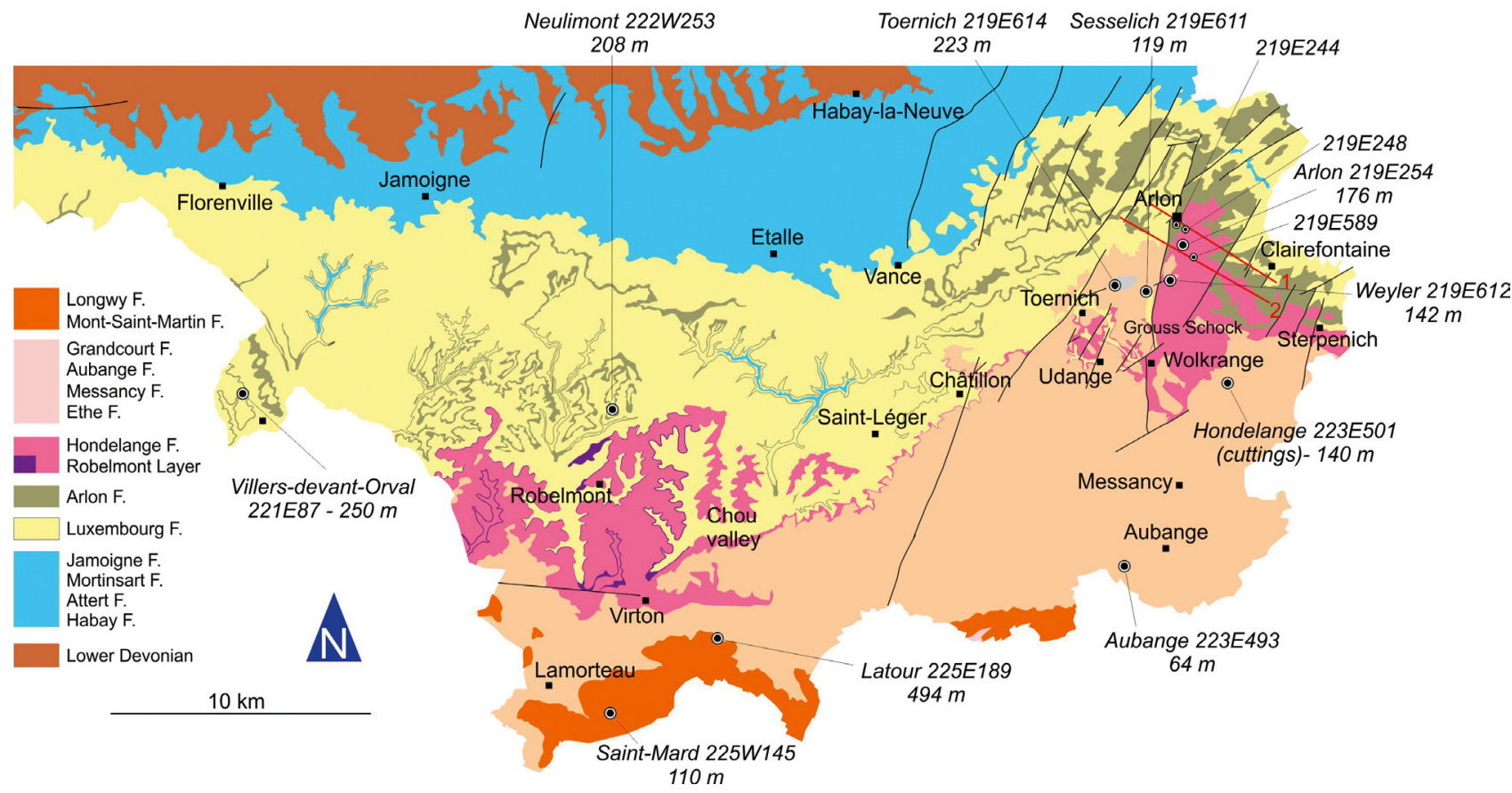

Figure 2. Simplified geological map of Belgian Lorraine, with selected boreholes. 1-2: cross sections through Grouss Schock (cf. Fig. 6). (Simplified after Belanger et al., 2002; Ghysel et al., 2002; Belanger, 2006 a, b; Ghysel \& Belanger, 2006).

laminated limestone $(182.1-172 \mathrm{~m})$. From $172 \mathrm{~m}$ to $167 \mathrm{~m}$, the limestone beds vanish and the silty marls are heavily bioturbated. The next facies, from $167 \mathrm{~m}$ to $159.6 \mathrm{~m}$ is again an alternation of dark grey bioturbated sandy-silty marls and decimeter-thick pale grey bioturbated limestone beds with lots of belemnites and crinoids. A reddish-brown slightly intraclastic level is observed near $164.5 \mathrm{~m}$. The top of the Hondelange Formation (159.6$157.6 \mathrm{~m}$ ) is a calcareous argillaceous dark grey sandstone, very rich in fossils. Vertical burrows are abundant throughout the formation. The boundary with the laminated silty argillite of the Ethe Formation is marked by a reddish-brown calcareous bed. According to its very good preservation, the Hondelange Formation in the Latour borehole may be considered as the lithostratotype of this unit.

Despite frequent lateral facies changes, the base of the Hondelange Formation is marked everywhere by centimetric to decimetric iron-rich beds also identified in some boreholes and interpreted as ferruginous hardgrounds. The formation is generally ordered in decimeter-thick locally very hardened beds which decrease in thickness towards the top and become laminated. The unit is topped everywhere by a decimeter-thick iron-rich level marking the transition to the Ethe Formation.

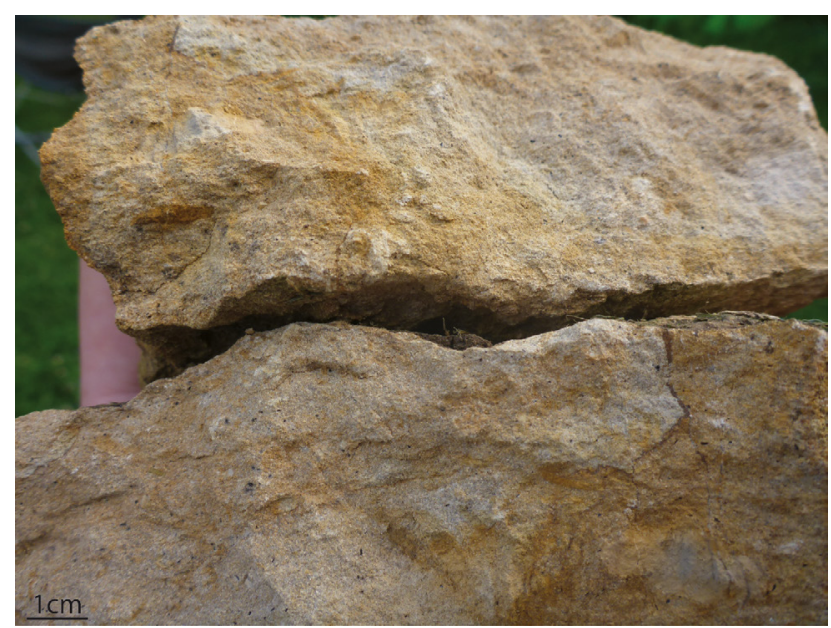

Figure 3. Typical facies of the Hondelange Formation (picture courtesy from S. Gruslin).
The northernmost extension of the outcrop area of the Hondelange Formation is limited to a SW-NE line passing just north of Arlon (Fig. 2). In the Arlon old brickyard, the formation is some decimeter-thick and is only represented by argillaceous and sandy layers rich in iron oxy-hydroxides on which the Ethe Formation lies (Fig. 5 A, E). In the Châtillon quarry, the thickness of the Hondelange Formation is around one decimeter only with locally meter-thick lenses of fossils-rich iron beds (Fig. 5C).

In Udange, on top of a ferruginous sandstone unit (Fig. $5 \mathrm{~B})$, lies a meter-thick succession of thin beds of argillaceous sandstone becoming foliated upwards. In the Toernich borehole (219E614), the Hondelange Formation is present as a ten meters thick unit of grey argillaceous sand rich in limonitic beds at the base. The thickness of the Hondelange Formation then increases southeast which corresponds to its main depositional area. It reaches $40 \mathrm{~m}$ SE of Arlon.

In this geographical area, important lateral facies variations together with an angular unconformity of approximately $10^{\circ}$ are highlighted on both sides of a N-S line running from Weyler to the flank of Grouss Schock hill. This N-S line also corresponds to the trace of the Arlon-Wolkrange fault (Fig. 2).

To the east, the Sterpenich region is a vast plain occupied by marls of the Strassen Member and dominated by residual hills of the Hondelange Formation. Predominant facies are sandy limestone and sandy argillite which are relatively more resistant to erosion and well-marked in the landscape.

Towards Grouss Schock (Fig. 6), the 219E254 borehole shows that the sandy-argillaceous limestone facies of the Hondelange Formation lies on sandy lenses of the Luxembourg Formation which disappears eastwards. The Weyler region can be considered as the easternmost extension of the Virton Member which increases in thickness to the southwest, reaching a maximum in Châtillon. In Grouss Schock, the Hondelange Formation rests both on Luxembourg and Arlon formations, reflecting its unconformable contact. Towards the top of the unit, the Hondelange facies is an argillaceous to sandy sandstone which more closely resembles the Luxembourg Formation than the Arlon Formation. However, the proportion of poorly sorted clay and organic matter gives a typical hybrid nature to this Hondelange facies (Figs 3 and 5D).

Between Saint-Léger and Virton, deep valleys were incised in the sandstone of the Luxembourg Formation, with flat surfaces marked at the occurrence of the Strassen and La Posterie argillaceous members (Fig. 2). The Hondelange Formation is composed of meter-thick argillaceous and calcareous sandstone 

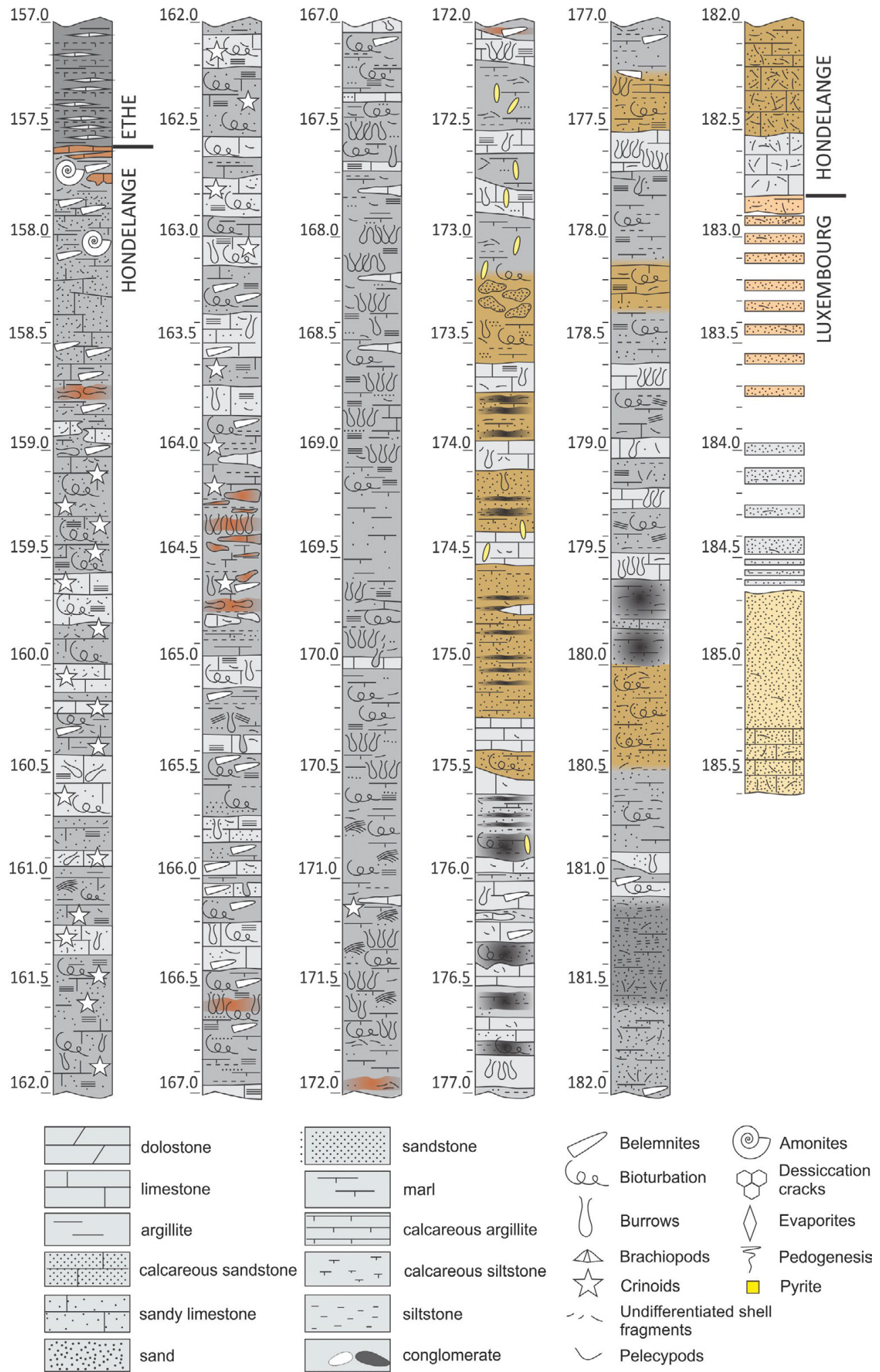

Figure 4. Lithologies and limits of the Hondelange Formation in the Latour borehole. Legend of symbols.

beds with decimeter-thick lenses of sands. Some levels are sandier with laminated or cross-laminated beds (Fig. 5D). Sandstones are poorly sorted and contain organic matter. Again, alteration gives to this formation a typical orange color.

From the meridian of the Chou valley towards the west, the Hondelange Formation reaches $20 \mathrm{~m}$ in thickness and has a basal metric layer of grey fossiliferous (Gryphaea) clay, the Layer of Robelmont. Towards the west, in the Robelmont region, this layer leads to numerous springs. As it has not been found in boreholes farther to the south, the Layer of Robelmont may be of local importance.

According to the presence of ammonites like Beaniceras luridum Simpson 1855 var. wright that belong to the Ibex Zone at the top of the unit in Châtillon, the age of the Hondelange Formation ranges

from the jamesoni to the davoei ammonite zones. The Luxembourg Formation below contains ammonites of the raricostatum Zone and the Ethe Formation above belongs to the margaritatus Zone.

\section{The sequence stratigraphic model}

The sequence stratigraphic interpretation proposed here is based on the classical model developed by Exxon and published by Vail et al. (1977), including the lowstand (LST), transgressive (TST) and highstand (HST) system tracts. According to the proposal by Plint \& Nummedal (2000), current sequence stratigraphic models often employ a four-fold subdivision of the base-level cycle: LST, TST, HST and FSST (falling-stage system tract). However, sequences developed in intracratonic area like Belgian Lorraine may differ from these models, based on passive margin sequences, 

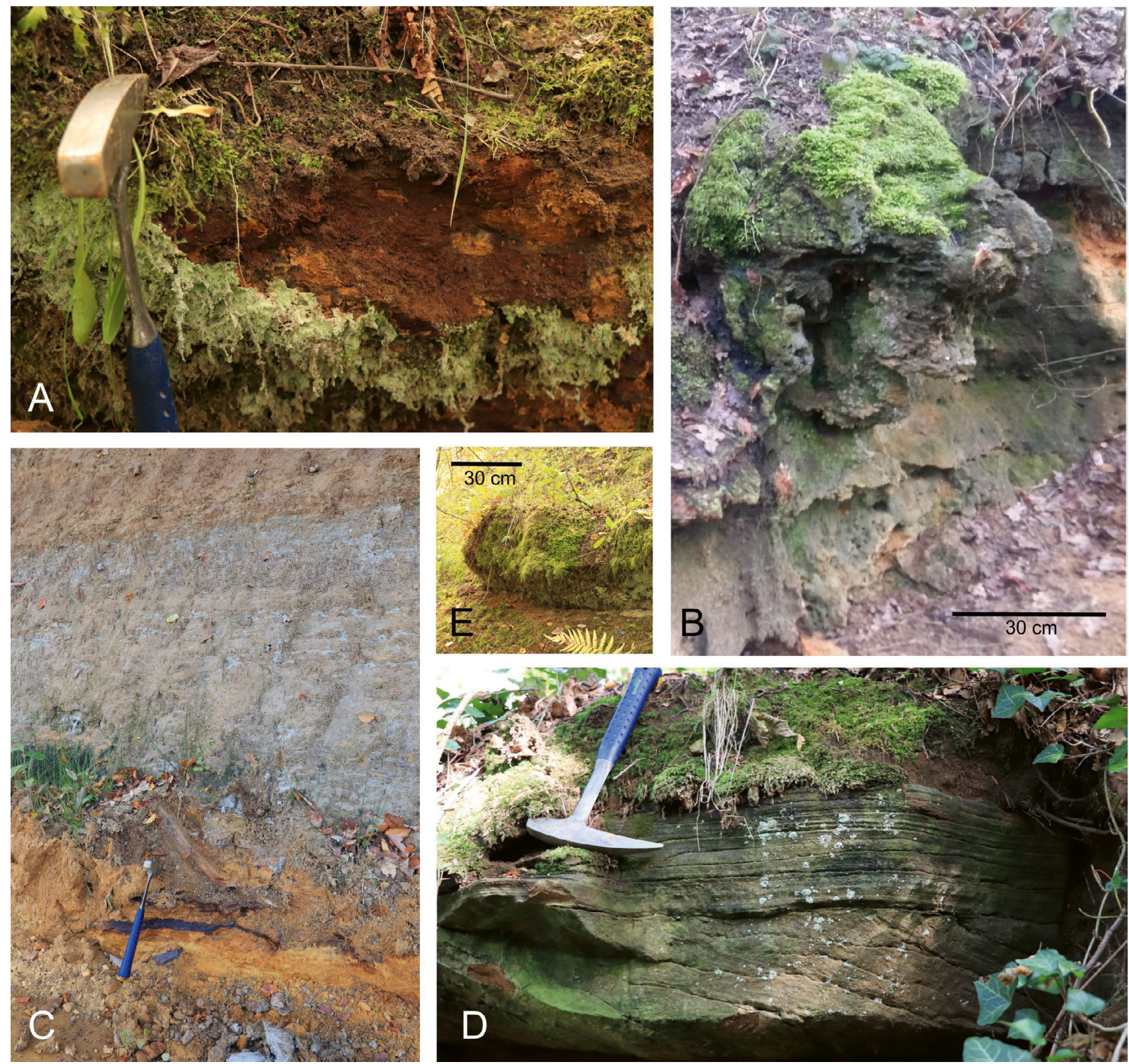

Figure 5. Lateral facies variations in the Hondelange Formation. A: basal iron-rich layer at Arlon old brickyard. B: basal iron-rich layer at Udange. C: iron crust between Luxembourg and Ethe formations where the Hondelange Formation is almost absent (Chattillon quarry). D: crossbedding in Hondelange argillaceous sandstone north of Virton and E: thick basal iron-rich layer at Arlon old brickyard.

by the wide extension of system tracts, different geometries and extremely varied facies (Vecsei \& Duringer, 2003). Moreover, the relatively proximal character of the units cropping out in Belgian Lorraine and G.-D. of Luxembourg should typically prevent any access to lowstand system tracts (LST), observed in more basinal settings. The expected sequential pattern should therefore consist of TST-HST-TST, etc. successions where TST is separated from HST by a maximum flooding surface (MFS) and HST is separated from TST by an amalgamated subaerial erosion and transgressive surface (TS). However, when the general accommodation is high, during sea level falls, even the shallowest area may preserve sediments, recorded as shelf margin system tracts (SMST) sensu Posamentier et al. (1988). Recommendations by Catuneanu (2006) suggest a merging of SMST and LST, because differences are poorly visible on discontinuous sections.

It should be noticed that other authors proposed sequence stratigraphic models for the Triassic of the SW German Basin (Vecsei \& Duringer, 2003), Lower Jurassic of the Paris Basin (Bessereau \& Guillocheau, 1993; Bessereau et al., 1995; Robin et al., 1996; Hallam, 2001; de Graciansky \& Jacquin, 2003; Gély \& Lorenz, 2006) or closer to us, the Triassic and Lower Jurassic of Belgium (Van den Bril \& Swennen, 2008). These models will be compared with the present results.
In order to better constrain the proposed sequence stratigraphic model, every transgressive surfaces and maximum flooding surfaces are listed in Table 1 with their description and precise location. Figure 7 illustrates some of these surfaces in the selected boreholes.

The so-called Ligurian transgressive cycle (de Graciansky et al., 1998) started in Belgian Lorraine during the Upper Triassic and ended during the Toarcian, with the widespread upper Toarcian-Aalenian regressive event and unconformity (Robin et al., 1996; de Graciansky \& Jacquin, 2003). The formations studied in the present work are part of this $2^{\text {nd }}$ order Ligurian cycle and the sequence stratigraphic model proposed hereunder consists of 3rd order sequences (Fig. 8).

The base of the first unit (TS1 of TST1) corresponds to the base of the Habay Formation, only visible in the Villers-devantOrval and Neulimont boreholes (Fig. 2), topping the Ardenne Lower Devonian slates. The TST1 encompasses the Habay, Attert and the base of the Mortinsart formations and ends with MFS1, characterized by green and dark grey clay/argillite or sandy-silty argillite (Fig. 8: 2, Villers; 11, Neulimont; 16, Latour; 34, Grund; 37, Grouft; 40, Consdorf). This TST1 marks the transition from continental environments to the first marine settings. Moderately developed pedogenetic structures (Wright, 1994) were observed 


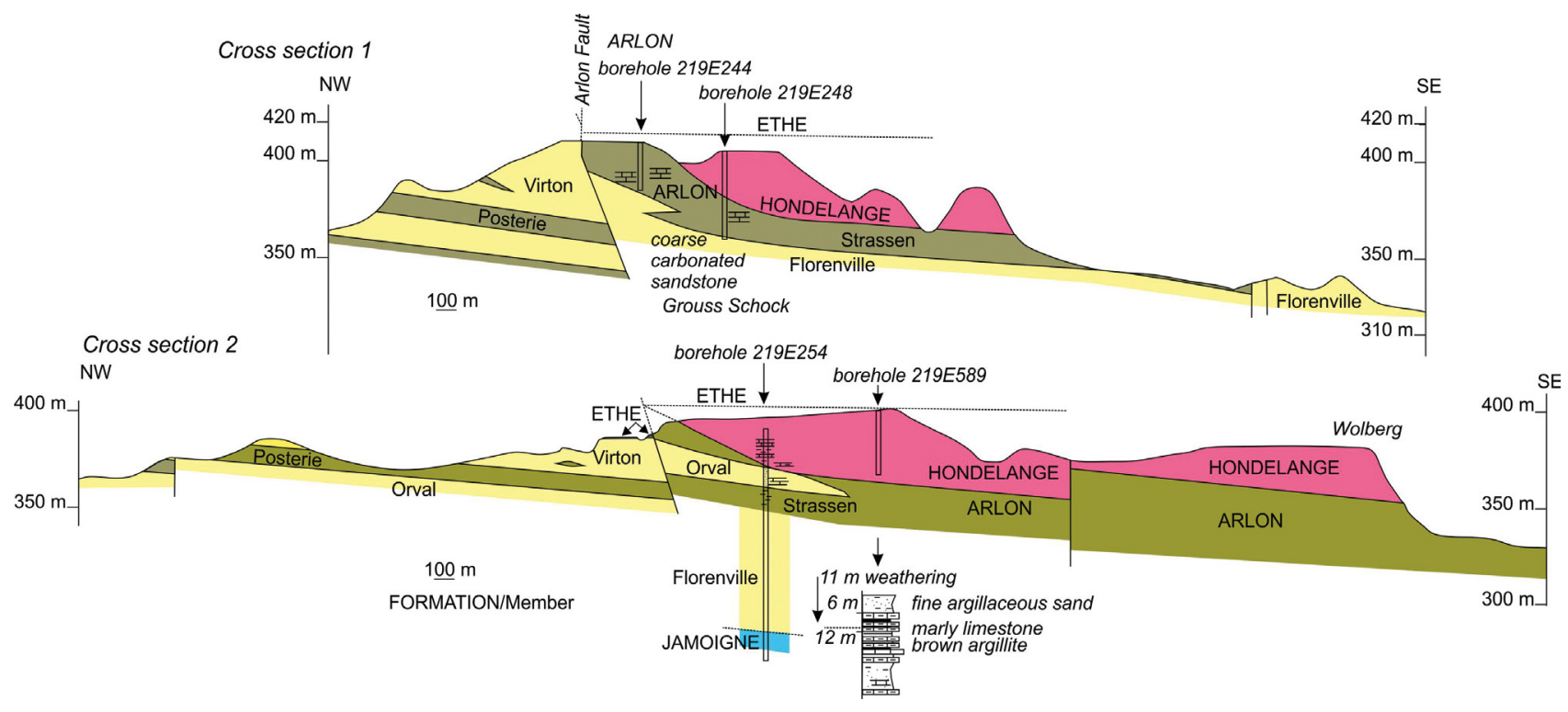

Figure 6. Cross sections through Grouss Schock, south of Arlon.

in the alluvial units of the Habay and Attert formations (Boulvain et al., 2001a). Additionally, poorly sorted quartzic or lithic arenites are present, together with sandstones and conglomerates locally cemented by gypsum or dolomite. Anhydrite occurs as decimetric fractured nodules with gypsum filling. These microfacies and associated lithologies point to an aridic lowland with sparse vegetation and limited precipitation of evaporites. Local and sporadic detrital supply is responsible for channelized or sheetlike immature sandstones and conglomerates (cf. Alsharhan \& Kendall, 2003; Donselaar \& Schmidt, 2005). The Mortinsart Formation (Rhaetian) is still characterized by pedogenetic argillite or dolomite and poorly sorted conglomerate, but locally, well-sorted pluridecimetric sandy or silty units are also observed, suggesting a first littoral influence, in addition to the Attert-like aridic continental facies. The MFS1 argillaceous facies reflects quiet, probably protected marine conditions. The relatively short HST1 corresponds to the upper part of the Mortinsart Formation, with dominating littoral sandy/silty or argillaceous facies. The Levallois Member, topping the Mortinsart Formation, is not present in the studied boreholes, but it is suggested that these argillaceous alluvial facies may represent a SMST. A similar interpretation is proposed by Van den Bril \& Swennen (2008).

As emphasized by Hallam (2001), several authors (Haq et al., 1987; de Graciansky et al., 1998) missed this first sequence, merging it within their models with the Early Hettangian TST2HST2 sequence. Bessereau \& Guillocheau (1993), Bessereau et al. (1995), Robin et al. (1996) and more recently, Bourquin et al. (2006) and Van den Bril \& Swennen (2008) did not make this confusion.

The base of the second sequence (TS2 of TST2) corresponds to the base of the Hettangian Jamoigne Formation. It is revealed by green argillite (3, Villers) or white sandstone (17, Latour) resting on pedogenetic versicolor argillite, grey gravely sandstone and argillite on grey sandstone (12, Neulimont), dark grey silty argillite on white sandstone (35, Grund), or grey laminated silty marl on green silty argillite (38, Grouft). In the Consdorf borehole, this surface is unclear. Obviously, TS2 marks a major transgression and TST2 facies, corresponding to the lower half of the Jamoigne Formation demonstrate the first spread of fully marine conditions after a long continental interval (Hallam, 2001). Facies are characteristic of a mid-ramp with thinly laminated silty argillite, located close to the storm wave base, silty argillite alternating with bioclastic or peloidic argillaceous packstone, sandstone and argillaceous sandstone, located in the storm wave zone (Aigner, 1985), calcareous sandstone or sandy packstone with peloids and well-sorted bioclastic and oolitic sandstone, both located on the inner ramp in the fair weather wave zone (Boulvain et al., 2017). Fauna has always an open marine character with prevalent bivalves and crinoids. The deepest conditions are recorded with MFS2: grey marl (4, Villers; 13, Neulimont), dark grey laminated silty marl or argillite (18, Latour; 39, Grouft; 42, Consdorf), and dark grey silty argillite (36, Grund). The HST2, as thick as the TST2, includes the upper part of the Jamoigne Formation and locally, the base of the Luxembourg Formation (Metzert Member).

The second sequence is recognized by Bessereau \& Guillocheau (1993), Bessereau et al. (1995) (MFS in the liasicus Zone), Robin et al. (1996) and Hallam (2001). This is less clear in the de Graciansky et al. (1998) and Van den Bril \& Swennen (2008) models where two distinct events (MFS2 and MFS3) are not undoubtedly distinguished.

The third sequence starts locally over an angular unconformity (14, Neulimont; 30, Tontelange), well visible in the Tontelange quarry and originally reported by Monteyne (1959). This amalgamated erosional/transgressive surface corresponds to calcareous sandstone over a grey coquina bed (5, Villers), grey sandstone over grey argillaceous sandstone or sandy marl (14, Neulimont; 25, Toernich), calcareous and sandstone gravels (19, Latour), dark orange silty sandstone over yellow sand (30, Tontelange) and grey bioturbated silty argillite on orange sandstone (43, Consdorf). The TST3 corresponds to the Florenville Member of the Luxembourg Formation followed by the lower part of the Arlon Formation. Facies are typical of an inner platform for the Luxembourg Formation (well-sorted bioclastic, peloidic or oolithic calcareous sand or sandstone). The moderate to good sorting and lack of mud is related to a relatively high energy and frequent coquina beds to proximal storms. These facies are in agreement with the sandwave model defined for the Luxembourg Sandstone (Berners, 1983; Guérin-Franiatte et al., 1991). Unidirectional cross stratifications have been related to asymmetric tidal flows inducing a dominant current (Mertens et al., 1983) and also related to lateral migration of the bars following the overall transgressive trend (Berners, 1983). The facies observed in the Arlon Formation resemble those of the Jamoigne Formation, a relatively wide variety of marine microfacies ranging from close to the storm wave zone to the fair weather wave zone. When compared with the Luxembourg Formation, most of the facies from the Arlon Formation are characterized by less sorted and finer-grained sand, together with more abundant organic matter and coal fragments (Boulvain et al., 2001a; Boulvain et al., 2017).The MFS3, separating the TST3 from the HST3 shows beige and brown sandstone or argillaceous sandstone (6, Villers; 20, Latour), grey marl (15, Neulimont; 26, Toernich), and grey silty or sandy argillite (31, Haebicht; 44, Consdorf). The HST3 encompasses the upper part of the Arlon Formation and/or the upper part of the Luxembourg Formation. 
Table 1. Location and main characteristics of the sequence stratigraphic surfaces.

\begin{tabular}{|c|c|c|c|c|}
\hline Borehole & $\mathrm{N}^{\circ}$ & Type & Depth (m) & Description \\
\hline \multirow[t]{7}{*}{$\begin{array}{l}\text { Villers-devant- } \\
\text { Orval }\end{array}$} & 1 & TS1 & 195.50 & $\begin{array}{l}\text { Purple and green conglomeratic dolomite on green slate and slate } \\
\text { fragments cemented by dolomite (Fig. 7) }\end{array}$ \\
\hline & 2 & MFS1 & 167.90 & Green and black argillite \\
\hline & 3 & $\mathrm{TS} 2$ & 162.15 & Green argillite on marmorized versicolor argillite \\
\hline & 4 & MFS2 & 107.00 & Grey marl \\
\hline & 5 & TS3 & 70.25 & Beige calcareous sandstone on grey coquina bed \\
\hline & 6 & MFS3 & 53.70 & Beige and brown oolithic sandstone \\
\hline & 7 & TS4 & 10.95 & Grey calcareous sandstone on orange sandstone \\
\hline \multirow[t]{2}{*}{ Saint-Mard } & 8 & TS5 & 86.10 & Grey silty marls on greenish-grey sandy limestone (Fig. 7) \\
\hline & 9 & MFS5 & 32.00 & Grey argillite \\
\hline \multirow[t]{6}{*}{ Neulimont } & 10 & $\mathrm{TS} 1$ & 201.00 & $\begin{array}{l}\text { Red and white conglomeratic dolomite on green, locally purple slate } \\
\text { and slate fragments }\end{array}$ \\
\hline & 11 & MFS1 & 165.20 & Greenish-grey argillite \\
\hline & 12 & $\mathrm{TS} 2$ & 152.35 & Grey gravely sandstone on grey sandstone (Fig. 7) \\
\hline & 13 & MFS2 & 118.50 & Grey marl \\
\hline & 14 & $\mathrm{TS} 3$ & 82.40 & Grey sandstone on grey argillaceous sandstone \\
\hline & 15 & MFS3 & 42.50 & Grey marl \\
\hline \multirow[t]{9}{*}{ Latour } & 16 & MFS1 & 356.30 & Black argillite \\
\hline & 17 & $\mathrm{TS} 2$ & 345.90 & White sandstone on green argillite with pedogenesis (Fig. 7) \\
\hline & 18 & MFS2 & 302.00 & Black laminated silty marl \\
\hline & 19 & $\mathrm{TS} 3$ & 253.70 & Calcareous and sandstone gravels \\
\hline & 20 & MFS3 & 233.00 & Beige argillaceous sandstone \\
\hline & 21 & TS4 & 182.80 & White sandy limestone on orange sandstone \\
\hline & 22 & MFS4 & 124.00 & Grey silty argillite \\
\hline & 23 & TS5 & 95.60 & Limestone gravels on grey silty argillite \\
\hline & 24 & MFS5 & 27.00 & Grey marl \\
\hline \multirow[t]{4}{*}{ Toernich } & 25 & TS3 & 206.80 & Grey sandstone on grey bioturbated sandy marl \\
\hline & 26 & MFS3 & 108.00 & Grey bioturbated marl \\
\hline & 27 & TS4 & 56.70 & Hardground with iron oxy-hydroxide crust (Fig. 7) \\
\hline & 28 & MFS4 & 29.00 & Grey marl \\
\hline Aubange & 29 & TS5 & 24.70 & Grey laminated sandy-silty marl on grey marl \\
\hline Bonnert & 30 & TS3+unconf. & 45.00 & Dark orange silty sandstone on yellow sand \\
\hline \multirow[t]{3}{*}{ Haebicht } & 31 & MFS3 & 74.00 & Greenish-grey silty argillite \\
\hline & 32 & TS4 & 52.70 & Greenish grey laminated silty argillite on bioturbated silty marl \\
\hline & 33 & MFS4 & 7.50 & Greenish-grey silty argillite \\
\hline \multirow[t]{3}{*}{ Grund } & 34 & MFS1 & 53.00 & Dark grey argillite \\
\hline & 35 & $\mathrm{TS} 2$ & 51.30 & Dark grey silty argillite on white sandstone (Fig. 7) \\
\hline & 36 & MFS2 & 33.50 & Dark grey silty argillite \\
\hline \multirow[t]{3}{*}{ Grouft } & 37 & MFS1 & 94.40 & Dark grey sandy argillite \\
\hline & 38 & $\mathrm{TS} 2$ & 89.40 & Grey laminated silty marl on green silty argillite \\
\hline & 39 & MFS2 & 85.00 & Grey laminated silty marl \\
\hline \multirow[t]{5}{*}{ Consdorf } & 40 & MFS1 & 67.00 & Grey laminated silty argillite \\
\hline & 41 & $\mathrm{TS} 2$ & 66.70 & Grey laminated silty argillite \\
\hline & 42 & MFS2 & 61.50 & Grey laminated silty argillite \\
\hline & 43 & $\mathrm{TS} 3$ & 47.50 & Grey bioturbated silty argillite on orange sandstone \\
\hline & 44 & MFS3 & 37.00 & Grey laminated sandy argillite \\
\hline
\end{tabular}




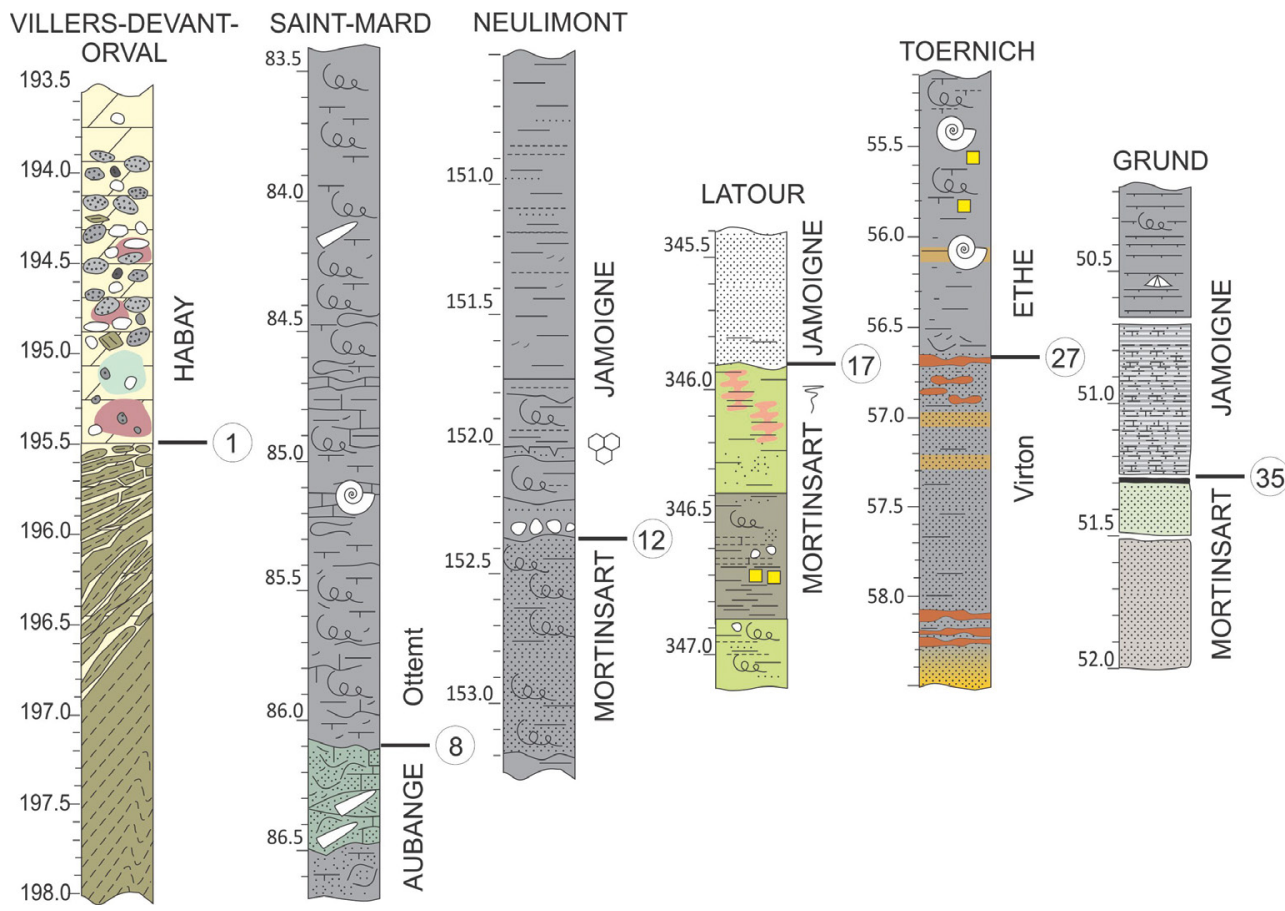

Figure 7. Examples of sequence stratigraphic surfaces. Circled numbers refer to Table 1 and Figure 8. Coordinates (Lambert 72): Villers: X 218490 Y 35076 Z 248; Saint-Mard X 233812 Y23788 Z 304; Neulimont X232595 Y 34762 Z 307. Latour X 236840 Y 26253 Z 312; Toernich X 252022 Y 39756 Z 437; Grund (LuRef) X 77640 Y 75014.
The third sequence is documented by Bessereau \& Guillocheau (1993), Bessereau et al. (1995) (MFS in the obtusum Zone), Hallam (2001), Gély \& Lorenz (2006) (MFS in the semicostatum Zone) and merged by de Graciansky et al. (1998) and Van den Bril \& Swennen (2008) with sequence 2.

The fourth sequence develops over a slight angular unconformity and is usually obvious to identify due to major changes in sedimentation pattern. In the boreholes, TS4 consists of white or grey calcareous sandstone over orange sandstone ( 7 , Villers; 21, Latour), a hardground with iron oxy-hydroxide crust (27, Toernich), and greenish-grey laminated silty argillite over bioturbated silty marl (32, Haebicht). The TST4 corresponds to the Hondelange Formation when present and to the lower part of the Ethe Formation. Facies vary from carbonated or argillaceous sandstone with moderate sorting (Hondelange Formation) to grey laminated silty argillite or marl (Ethe Formation). The MFS4 corresponds to grey silty argillite (22, Latour; 33, Haebicht) or marl (28, Toernich). The top of the Ethe Formation, together with the Messancy and Aubange formations form the HST4, characterized by facies ranging from below the storm wave zone (grey laminated silty argillite or marl) to the base of the fair weather wave zone (heavily bioturbated argillaceous limestone with silt-sized quartz, micas, crinoids and bivalves).

The fourth sequence is also observed by Bessereau \& Guillocheau (1993), Bessereau et al. (1995), Gély \& Lorenz (2006) (MFS in the margaritatus Zone) and Robin et al. (1996). Hallam (2001) did not record this sequence. Van den Bril \& Swennen (2008) localizes the MFS4 in the Ethe Formation, like in the present work, but interpreted the Aubange Formation as a LST.

The base of the fifth sequence corresponds to a well-marked TS, grey silty marls over greenish-grey sandy limestone (8, SaintMard), limestone gravels on grey silty argillite (23, Latour) and grey laminated sandy-silty marl on grey marl (29, Aubange). The TST5 locally includes the top of the Aubange Formation and more largely, the Grandcourt Formation. Facies are among the deepest recorded, with laminated dark grey argillites or marls. Bioturbation is commonly lacking, suggesting permanent dysoxic bottom conditions. Very thin silty laminae are interpreted as distal tempestites (Guillocheau, 1983). In this context, MFS5 is evidenced by unbioturbated grey argillite or marl (9, SaintMard; 24, Latour). This particular surface corresponds to the MFS of the full Ligurian transgressive cycle (de Graciansky et al., 1998) and to the maximum extension of the Lower Jurassic sea on the Ardenne lowlands. The HST5 is poorly documented in the boreholes by grey bioturbated silty argillites (Saint-Mard).
The fifth sequence is recognized by all the above mentioned authors, stressing the spread of black shales in Europe (Hallam, 2001). The MFS5 is positioned in the serpentinum Zone by Bessereau \& Guillocheau (1993), Bessereau et al. (1995) and Gély \& Lorenz (2006).

\section{Sequence stratigraphy and magnetic susceptibility}

The relations existing between MS and formations on one hand and between MS and microfacies on the other have already been preliminary investigated by Boulvain et al. (2017). The present study preferentially focused on the relations between MS and system tracts.

Changes in magnetic susceptibility (MS) in sedimentary successions are attributed to sea level variations (Ellwood et al., 2000). The major influence of sea level on the MS signal is related to the strong link between MS and detrital components assuming that the detrital input is generally controlled by eustasy or climate. In this way, a lowering of sea-level (regression) increases the proportion of exposed continental area, increases erosion and leads to higher MS values, whereas rising sea level (transgression) decreases MS (Crick et al., 2001). Climatic variations influence MS through changes in rainfall (high rainfall increases erosion and MS), glacial-interglacial periods (glacial periods are related to glacier erosion and to marine regression and both effects increase MS) and pedogenesis (formation of magnetic minerals in soils; Tite \& Linington, 1975). Furthermore, early and late diagenesis can be responsible for MS variations through mineralogical transformations, dissolution or authigenesis (McCabe \& Elmore, 1989; Zegers et al., 2003).

A series of 2089 samples coming from all the formations surveyed in this study were analyzed. Table 2 gives the number of samples, mean value, median and standard deviation for the formations and system tracts intersected by the boreholes. Figure 9 proposes a synthetic view of MS versus logs and system tracts for the Consdorf, Grouft, Grund, Haebicht, Tontelange and Rumelange boreholes, together with new MS data for the Latour and Neulimont boreholes.

A comparison between MS and microfacies has shown a clear positive correlation, suggesting that the MS signal is primary, as already stated by Dechamps et al. (2015) for the BajocianBathonian of the Azé caves. Moreover, the MS values regularly decrease from the marine distal to the marine proximal facies. The same pattern was recorded earlier for older carbonate ramps (e.g. Middle Devonian: Mabille \& Boulvain, 2007; Tournaisian: Bertola et al., 2013). This was interpreted by Da Silva et al. (2009) as the consequence of local water agitation in the shallower parts 


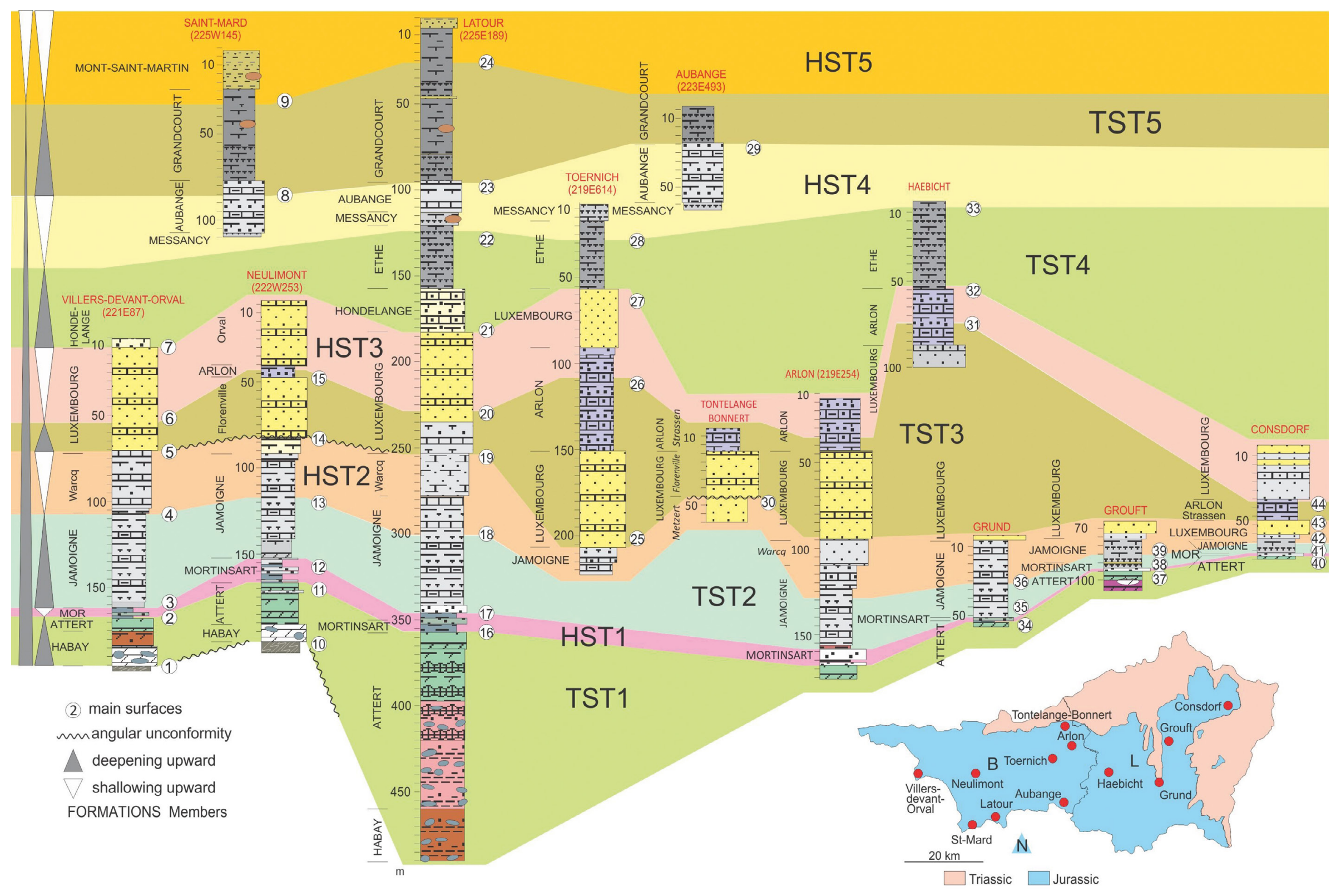

Figure 8. Sequence stratigraphic interpretation of boreholes with main surfaces numbered. 
Table 2. MS $\left(\mathrm{m}^{3} / \mathrm{kg}\right)$ versus formations and system tracts for all boreholes.

\begin{tabular}{|l|c|l|c|l|}
\hline Formations & $\begin{array}{c}\text { Number of } \\
\text { samples }\end{array}$ & \multicolumn{1}{|c|}{$\begin{array}{c}\text { Mean MS } \\
\left(\mathrm{m}^{3} / \mathrm{kg}\right)\end{array}$} & $\begin{array}{c}\text { Standard deviation } \\
\left(\mathrm{m}^{3} / \mathrm{kg}\right)\end{array}$ & \multicolumn{1}{|c|}{$\begin{array}{c}\text { Median } \\
\left(\mathrm{m}^{3} / \mathrm{kg}\right)\end{array}$} \\
\hline Ethe & 213 & $1.44 \mathrm{E}-07$ & $1.66 \mathrm{E}-07$ & $1.18 \mathrm{E}-07$ \\
Hondelange & 22 & $7.22 \mathrm{E}-08$ & $9.49 \mathrm{E}-08$ & $5.25 \mathrm{E}-08$ \\
Arlon & 264 & $4.56 \mathrm{E}-08$ & $2.24 \mathrm{E}-08$ & $4.80 \mathrm{E}-08$ \\
Luxembourg & 668 & $2.02 \mathrm{E}-08$ & $6.16 \mathrm{E}-08$ & $1.10 \mathrm{E}-08$ \\
Jamoigne & 543 & $3.69 \mathrm{E}-08$ & $1.51 \mathrm{E}-08$ & $3.71 \mathrm{E}-08$ \\
Mortinsart & 73 & $5.42 \mathrm{E}-08$ & $3.54 \mathrm{E}-08$ & $5.04 \mathrm{E}-08$ \\
Attert & 220 & $7.32 \mathrm{E}-08$ & $3.58 \mathrm{E}-08$ & $7.73 \mathrm{E}-08$ \\
Habay & 58 & $6.26 \mathrm{E}-08$ & $3.90 \mathrm{E}-08$ & $5.39 \mathrm{E}-08$ \\
\hline TST1 & 311 & $6.91 \mathrm{E}-08$ & $3.56 \mathrm{E}-08$ & $6.82 \mathrm{E}-08$ \\
HST1 & 70 & $5.55 \mathrm{E}-08$ & $3.45 \mathrm{E}-08$ & $5.36 \mathrm{E}-08$ \\
TST2 & 264 & $4.32 \mathrm{E}-08$ & $1.35 \mathrm{E}-08$ & $4.41 \mathrm{E}-08$ \\
HST2 & 411 & $2.98 \mathrm{E}-08$ & $4.33 \mathrm{E}-08$ & $2.53 \mathrm{E}-08$ \\
TST3 & 461 & $2.72 \mathrm{E}-08$ & $6.32 \mathrm{E}-08$ & $1.30 \mathrm{E}-08$ \\
HST3 & 337 & $2.72 \mathrm{E}-08$ & $2.62 \mathrm{E}-08$ & $1.58 \mathrm{E}-08$ \\
TST4 & 204 & $1.22 \mathrm{E}-07$ & $9.07 \mathrm{E}-08$ & $1.17 \mathrm{E}-07$ \\
HST4 & 31 & $2.40 \mathrm{E}-07$ & $3.71 \mathrm{E}-07$ & $1.20 \mathrm{E}-07$ \\
\hline
\end{tabular}

of a ramp, preventing the detrital particles from settling down and to the higher sedimentation rate that dilutes the magnetic minerals. More precisely, in this study, the sandstones and sandy limestones show the weakest MS signal, while the pelitic rocks are characterized by a strong and fluctuating MS signal (Boulvain et al., 2017). This was also observed in Lower Devonian marine sandstone-shale alternations by Michel et al. (2010, fig. 7). The stronger signal recorded from the Attert argillites and dolomites, is perhaps related to pedogenesis or proximity of the terrestrial sources (Tite \& Linington, 1975; Babek et al., 2013, Boulvain et al., 2017).

From a lithostratigraphical point of view, first observations have shown that MS values are the weakest for the Luxembourg Formation (except for some peaks whose origin is not yet understood) while they are relatively high for the Ethe, Hondelange, Arlon and Attert formations (Table 2; Fig. 10) (Boulvain et al., 2017).

This being so, and Figure 8 showing that the system tract model broadly follows lithostratigraphy, it is not surprising that Figures 10A and B globally exhibit the same tendency for the MS signal. No special effect of the system tract nature is observed: the different sequences (1-4) being characterized by close and consistent MS levels for TST's and HST's. This is barely the case for Paleozoic carbonates where LST's systematically show high values while TST's are characterized by decreasing values and HST's by the lowest values (Da Silva \& Boulvain, 2006; Bertola et al., 2013). However, in Belgian Lorraine, MS varies from one depositional sequence to the other, decreasing from sequence 1 to 3 and increasing with sequence 4 . A first interpretation suggests the continental nature of the first sequence to account for the relatively higher MS values, linked to pedogenesis or to the close proximity of detrital sources (Tite \& Linington, 1975; Babek et al., 2013) and the generalization of dysoxic conditions for the high MS values of sequence 4. Interestingly, Grabowski et al. (2015) showed that oxygen conditions and productivity were important factors controlling magnetite distribution in Eifelian dolomites. Preservation of magnetite, the main carrier of the MS signal, is enhanced for dysoxic-anoxic sediments.

\section{Conclusion}

The main purposes of this study were (1) to propose a detailed description of the Hondelange Formation, supporting an amendment of its lithostratigraphic status and (2) to propose and argue a sequence stratigraphic model for the Triassic-Jurassic transgressive prism in Belgian Lorraine.

For the Sinemurian-Pliensbachian interval, the new geological maps of Wallonia present two synchronous formations distinguished by contrasting lithologies, the Luxembourg Formation with a sandy facies and the Arlon Formation which is argillaceous. The Hondelange unit was included as a member in the uppermost part of the Arlon Formation. However, this has proven to be impractical owing to its mixed lithology, combining sandstone, sand, clay/argillite, and limestone. The typical facies of the Hondelange unit is a poorly sorted grey to yellowish-grey argillaceous calcareous sandstone, with a distinctive orange alteration color. In addition to this peculiar lithology, lateral facies variations are very common, both in $\mathrm{N}-\mathrm{S}$ and $\mathrm{W}-\mathrm{E}$ directions. At least, a clear angular unconformity is observed locally at the base of the Hondelange unit, which may rest either on the Luxembourg or the Arlon formations. These arguments led us to propose to modify the lithostratigraphic status of the Hondelange unit from a member of the Arlon Formation to a full-blown formation.

Due to its very proximal setting, the sequence stratigraphic pattern in Belgian Lorraine consist of TST-HST-TST, etc. successions where TST is separated from HST by a maximum flooding surface (MFS) and HST is separated from TST by an amalgamated subaerial erosion and transgressive surface (TS). Five depositional sequences are distinguished, from Upper Triassic to upper Toarcian, with well-marked sequential surfaces, identified in outcrops and boreholes. These $3^{\text {rd }}$ order depositional sequences are integrated in the major 2nd order Ligurian transgressive cycle. Several tests were carried on to evaluate the formation and sequence-dependence of the MS signal. As already stated, the sandstones and sandy limestones show the weakest MS signal, while the pelitic rocks are characterized by a strong and fluctuating MS signal. Finally, even if surprisingly, TST's and HST's are characterized by a relatively similar MS signal, a long-term lowering of this signal is highlighted from the first to the third sequences, before a drastic rise probably due to the 


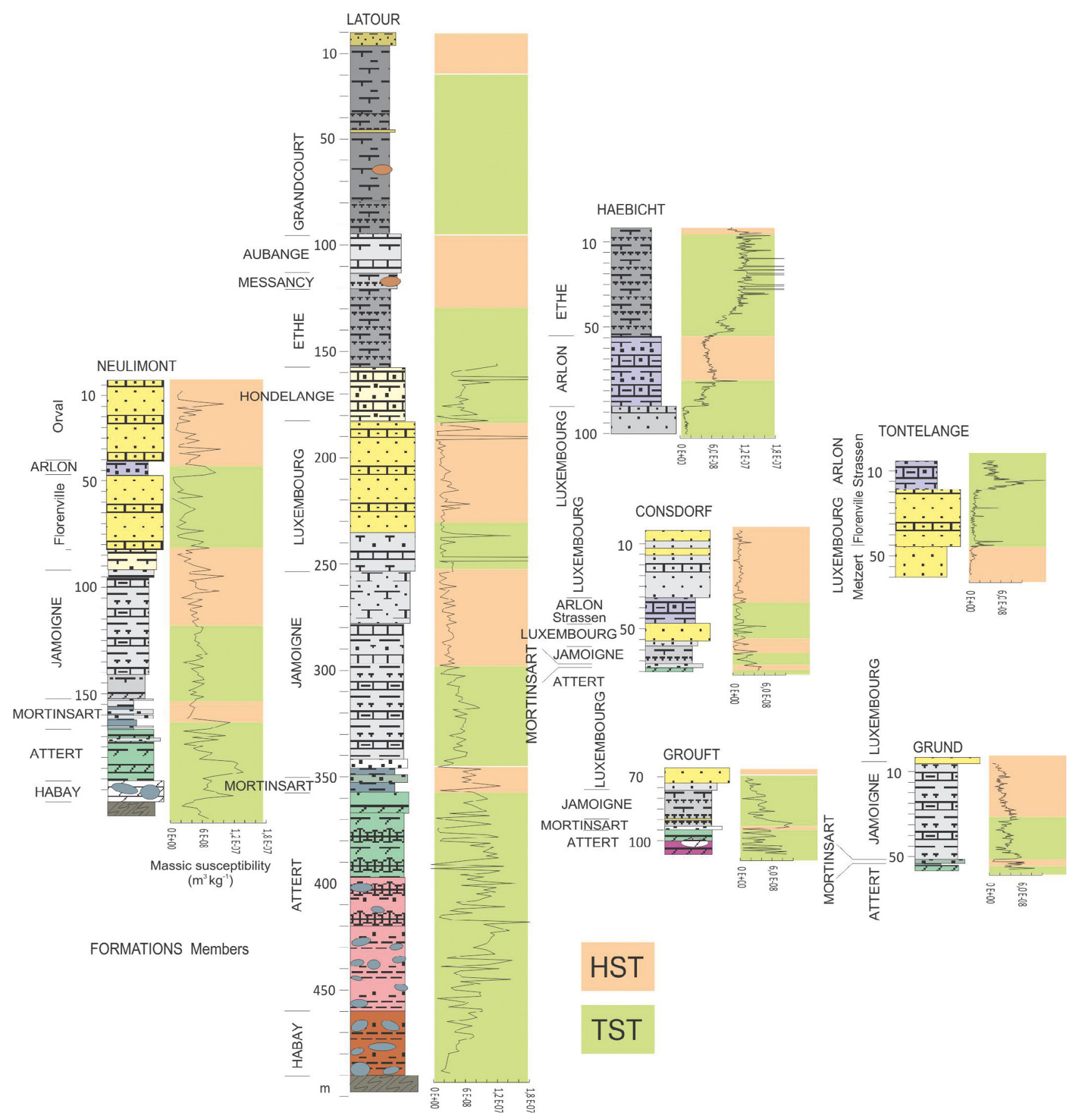

Figure 9. Sequence stratigraphic interpretation of boreholes and MS signal (modified after Boulvain et al., 2017).

generalization of dysoxic conditions during the deposition of the Ethe and Grandcourt formations.

\section{Acknowledgements}

The authors warmly thank all the colleagues who shared their observations and comments during many fieldtrips in Belgian Lorraine. Special thanks are due to reviewers R. Colbach (Geological Survey, G.-D. of Luxembourg) and G.J. Weltje (KU Leuven, Belgium) for interesting suggestions and comments. A. Anceau is warmly acknowledged for careful editing of this manuscript.

\section{References}

Aigner, T., 1985. Storm depositional systems: dynamic stratigraphy in modern and ancient shallow-marine sequences. Springer, Berlin, Lecture Notes in Earth Sciences, 3, 174 p. https://doi.org/10.1007/ $\mathrm{BFb} 0011411$
Alsharhan, A.S. \& Kendall, C.G.St.C., 2003. Holocene coastal carbonates and evaporites of the southern Arabian Gulf and their ancient analogues. Earth-Science Reviews, 61, 191-243. https://doi. org/10.1016/S0012-8252(02)00110-1

Babek, O., Kalvoda, J., Cossey, P., Simicek, D., Devuyst, F. X. \& Hargreaves, S. 2013. Facies and petrophysical signature of the Tournaisian/Visean (Lower Carboniferous) sea-level cycle in carbonate ramp to basinal settings of the Wales-Brabant massif, British Isles. Sedimentary Geology, 284, 197-213. https://doi. org/10.1016/j.sedgeo.2012.12.008

Belanger, I., 2006a. Carte géologique de Wallonie : Lamorteau - Ruette 71/5-6. 1/25 000. Namur, Ministère de la Région wallonne, Direction générale des ressources naturelles et de l'environnement, avec une notice explicative de $33 \mathrm{p}$.

Belanger, I., 2006b. Carte géologique de Wallonie : Meix-devant-Virton - Virton 71/1-2. 1/25 000. Namur, Ministère de la Région wallonne, Direction générale des ressources naturelles et de l'environnement, avec une notice explicative de $30 \mathrm{p}$. 


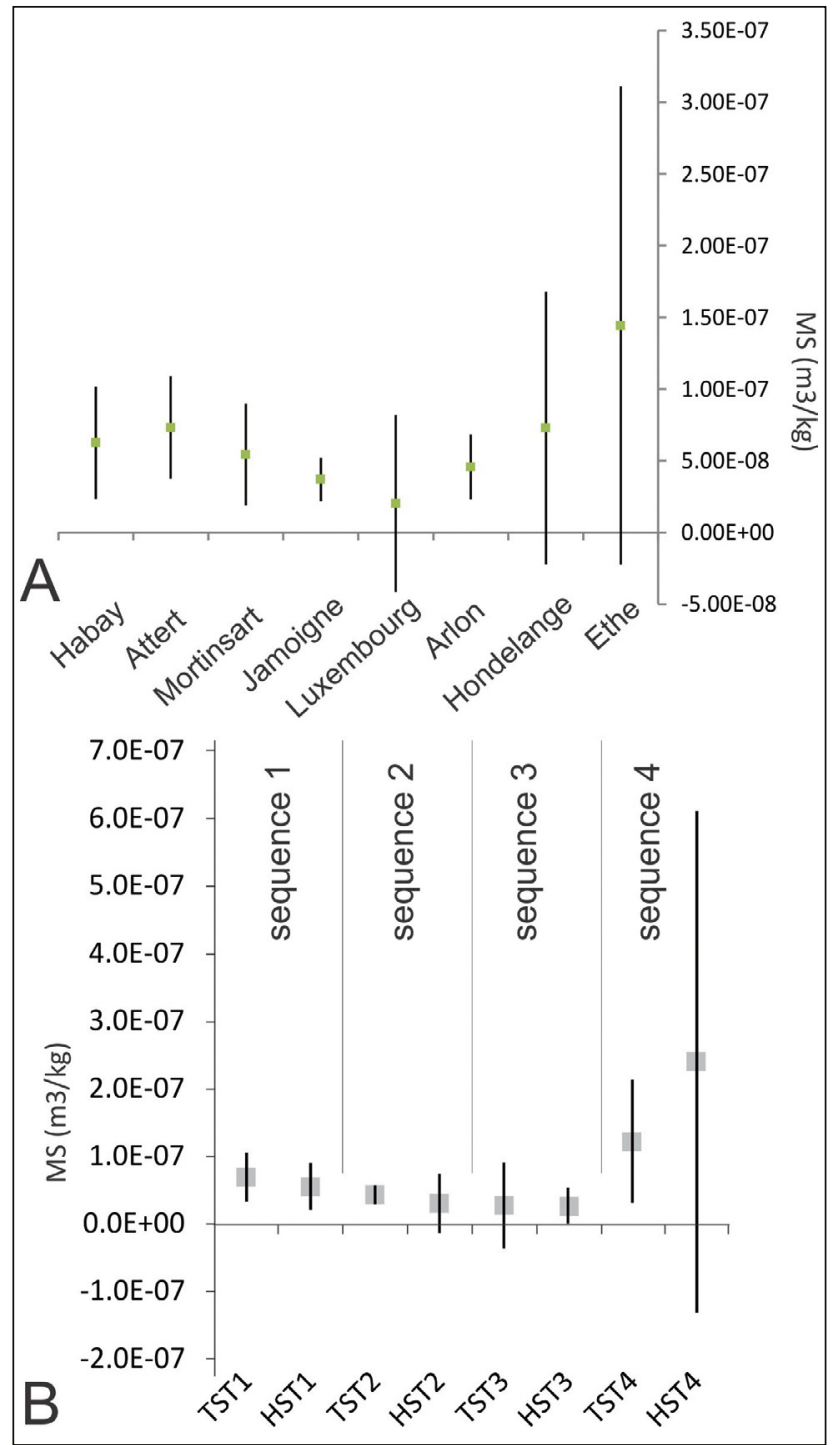

Figure 10. A: Mean values and standard deviation of MS versus formations. B: Mean values and standard deviation of MS versus system tracts and depositional sequences.

Belanger, I., Delsate D., Ghysel, P., Laloux, M. \& Boulvain, F., 2002. Saint-Léger - Messancy 71/3-4 - Musson - Le Fays 71/7-8 Houwald 72/1. 1/25 000. Namur, Ministère de la Région wallonne, Direction générale des ressources naturelles et de l'environnement, avec une notice explicative de $35 \mathrm{p}$.

Berners, H.P., 1983. A Lower Liassic offshore bar environment. Contribution to the sedimentology of the Luxembourg Sandstone. Annales de la Société géologique de Belgique, 106, 87-102.

Bertola, C., Boulvain, F., Da Silva, A.-C. \& Poty, E. 2013. Sedimentology and magnetic susceptibility of Mississippian (Tournaisian) carbonate sections in Belgium. Bulletin of Geosciences, 88, 69-82.

Bessereau, G. \& Guillocheau, F., 1993. Stratigraphie séquentielle et distribution de la matière organique dans le Lias du Bassin de Paris. Comptes Rendus de l'Académie des Sciences de Paris, Série 2, 316 , 1271-1278.

Bessereau, G., Guillocheau, F. \& Huc, A.Y., 1995. Source rock occurrence in a sequence stratigraphic framework: the example of the Lias of the Paris Basin. American Association of Petroleum Geologists, Studies in Geology, 40, 273-301.

Bintz, J. \& Storoni, A., 2009. Les minerais de fer luxembourgeois. Editions Schortgen, Esch-sur-Alzette, $24 \mathrm{p}$.

Boulvain, F. \& Monteyne, R. 1993. Colonne lithologique du sondage de Latour (494 m): une coupe de référence pour le Secondaire de la Gaume. Belgian Geological Survey Professional Papers, 267, 35 p.

Boulvain, F., Delsate, D. \& Maubeuge, P.L., 1995. Description et interprétation stratigraphique de quatre sondages dans le Secondaire de la Gaume (Neulimont, Aubange, Saint-Mard et Toernich). Belgian Geological Survey Professional Papers, 277, 51 p.

Boulvain, F., Delsate, D., Gulinck, M., Laga, P. \& Maubeuge, P.L., 1996. Description lithostratigraphique et pétrographie du sondage 221E87 de Villers-devant-Orval (Trias, Lias de la Gaume, Belgique). Belgian Geological Survey Professional Papers, 281, 26 p.

Boulvain, F., Belanger, I., Delsate, D., Dosquet, D., Ghysel, P., Godefroit, P., Laloux, M., Roche, M., Teerlynck, H. \& Thorez, J., 2001a. New lithostratigraphical, sedimentological, mineralogical and palaeontological data on the Mesozoic of Belgian Lorraine: a progress report. Geologica Belgica, 3, 3-33.

Boulvain, F., Belanger, I., Delsate, D., Ghysel, P., Godefroit, P., Laloux, M., Monteyne, R. \& Roche, M., 2001b. Triassic and Jurassic lithostratigraphic units (Belgian Lorraine). In Bultynck P. \& Dejonghe, L. (eds), Guide to a revised lithostratigraphic scale of Belgium. Geologica Belgica, 4, 113-119.

Boulvain, F., Belanger, I., Colbach, R., Dechamps, S., Delsate, D., Deligny, D., Ghysel, P., Michel, J., Philippo, S. \& Ramlot, B., 2017. New sedimentological data from Triassic to Jurassic boreholes (Bonnert, Haebicht, Grouft, Grund, Consdorf) and sections (Tontelange, Differdange, Rumelange) from Southern Belgium and Luxembourg. Belgian Geological Survey Professional Papers, 319, 43 p.

Bourquin, S., Peron, S. \& Durand, M. 2006. Lower Triassic sequence stratigraphy of the western part of the Germanic Basin (West of Black Forest): Fluvial system evolution through time and space. Sedimentary Geology, 186, 187-211. https://doi.org/10.1016/j. sedgeo.2005.11.018

Catuneanu, O., 2006. Principles of Sequence Stratigraphy. Elsevier, Amsterdam, $375 \mathrm{p}$

Crick, R.E., Ellwood, B.B., Hladil, J., El Hassani, A., Hrouda, F. \& Chlupác, I., 2001. Magnetostratigraphy susceptibility of the Prídolian-Lochkovian (Silurian-Devonian) GSSP (Klonk, Czech Republic) and a coeval sequence in Anti-Atlas Morocco. Palaeogeography, Palaeoclimatology, Palaeoecology, 167, 73-100. https://doi.org/10.1016/S0031-0182(00)00233-9

Da Silva, A.-C. \& Boulvain, F., 2006. Upper Devonian carbonate platform correlations and sea level variations recorded in magnetic susceptibility. Palaeogeography, Palaeoclimatology, Palaeoecology, 240, 373-388. https://doi.org/10.1016/j.palaeo.2006.02.012

Da Silva, A.-C., Potma, K., Weissenberger, J. A., Whalen, M. T., Humblet, M., Mabille, C. \& Boulvain, F. 2009. Magnetic susceptibility evolution and sedimentary environments on carbonate platform sediments and atolls, comparison of the Frasnian from Belgium and Alberta, Canada. Sedimentary Geology, 214, 3-18. https://doi. org/10.1016/j.sedgeo.2008.01.010

Dechamps, S., Da Silva, A. C. \& Boulvain, F., 2015. Magnetic susceptibility and facies relationship in Bajocian-Bathonian carbonates from the Azé caves, southeastern Paris Basin, France. Geological Society, London, Special Publications, 414, 93-110. https://doi.org/10.1144/SP414.11

de Graciansky, P. \& Jacquin, T., 2003. Evolution des structures et de la paléogéographie au passage Lias-Dogger dans le bassin de Paris d'après les données de la subsurface. Bulletin de la Société géologique de France, 174, 3-17.

de Graciansky, P., Jacquin, T. \& Hesselbo, S.P., 1998. The Ligurian cycle: an overview of Lower Jurassic $2^{\text {nd }}$ order transgressive/ regressive facies cycles in Western Europe. In de Graciansky, P., Hardenbol, J., Jacquin, T. \& Vail, P.R. (eds), Mesozoic and Cenozoic sequence stratigraphy of European basins. Society for Economic Paleontologists and Mineralogists Special Publications, 60, 467-479. https://doi.org/10.1016/S0928-8937(01)80012-6

Dera, G., Brigaud, B., Monna, F., Laffont, R., Pucéat, E., Deconinck, J.F., Pellenard, P., Joachimski, M. \& Durlet, C., 2011. Climatic ups and downs in a disturbed Jurassic world. Geology, 39, 215-218. https:// doi.org/10.1130/G31579.1

Dewalque, G., 1854. Note sur les divers étages qui constituent le Lias moyen et le Lias supérieur dans le Luxembourg et les contrées voisines. Bulletin de la Société géologique de France, 11, 234 \& 546.

Dittrich, D., 2017. Marine Signale im Höheren Buntsandstein der TrierLuxemburger Bucht? Teil 1 : Auffällige Horizonte und besondere Faziesmerkmale. Mainzer geowissenschaftliche Mitteilungen, 45, $7-92$.

Donselaar, M.E. \& Schmidt, J.M., 2005. Integration of outcrop and borehole image $\operatorname{logs}$ for high-resolution facies interpretation: example from a fluvial fan in the Ebro Basin, Spain. Sedimentology, 52, 1021-1042. https://doi.org/10.1111/j.1365-3091.2005.00737.x

Dormal, V., 1894. Compte rendu de l'excursion de la Société belge de géologie, de paléontologie et d'hydrologie dans les terrains jurassique et triasique des environs d'Arlon et de Florenville. Bulletin de la Société belge de Géologie, Paléontologie, Hydrologie, 8, 102-129.

Dormal, V. \& Purves, J-C., 1897. Carte géologique de la Belgique : Meix-devant-Virton - Virton, $n^{\circ} 222.1 / 40$ 000. Bruxelles, Institut cartographique militaire.

Dumont, A., 1842. Mémoire sur les terrains triasique et jurassique dans la province de Luxembourg. Nouveaux Mémoires de l'Académie royale des Sciences et Belles-Lettres de Bruxelles, 15, 1-36. 
Ellwood, B.B., Crick, R.E., El Hassani, A., Benoist, S.L. \& Young, R.H., 2000. Magnetosusceptibility event and cyclostratigraphy method applied to marine rocks: Detrital input versus carbonate productivity. Geology, 28, 1135-1138. https://doi.org/10.1130/00917613(2000)28\%3C1135:MEACMA\%3E2.0.CO;2

Faber, A., Gamez, P., Hanzo, M. \& Mirambet, F., 1999. Le fer. In Mines de Lorraine et du Luxembourg. Journée d'étude d'automne (1-3 octobre 1998). Bulletin d'Information des Géologues du Bassin de Paris, 36, 27-33.

Gély, J.P. \& Lorenz, J., 2006. Le Lias et le Dogger du sud du Bassin parisien (France): rôle de la tectonique syn-sédimentaire et reconstitutions paléogéographiques à l'échelle de la biozone d'ammonite. Geobios, 39, 631-649. https://doi.org/10.1016/j.geobios.2005.06.005

Ghysel, P. \& Belanger, I., 2006. Carte géologique de Wallonie : Florenville - Izel 67/7-8 - Villers-devant-Orval 70/3-4. 1/25 000. Namur, Ministère de la Région wallonne, Direction générale des ressources naturelles et de l'environnement, avec une notice explicative de $61 \mathrm{p}$.

Ghysel, P., Monteyne, R., Laloux, M., Boulvain, F. \& Delsate, D., 2002. Carte géologique de Wallonie : Tintigny - Etalle 68/5-6. 1/25 000. Namur, Ministère de la Région wallonne, Direction générale des ressources naturelles et de l'environnement, avec une notice explicative de $41 \mathrm{p}$.

Grabowski, J., Narkiewicz, M. \& De Vleeschouwer, D. 2015. Forcing factors of the magnetic susceptibility signal in lagoonal and subtidal depositional cycles from the Zachełmie section (Eifelian, Holy Cross Mountains, Poland). In Da Silva, A. C., Whalen, M.T., Hladil, J., Chadimova, L., Chen, D., Spassov, S., Boulvain, F. \& Devleeschouwer, X. (eds), Magnetic Susceptibility Application A Window onto Ancient Environments and Climatic Variations. Geological Society, London, Special Publications, 414, 225-244. https://doi.org/10.1144/SP414.5

Guérin-Franiatte, S. \& Muller, A., 1986. L’Hettangien dans le NE du Bassin de Paris: biostratigraphie et évolution sédimentaire. Annales de la Société géologique de Belgique, 109, 415-429.

Guérin-Franiatte, S., Hary, A. \& Muller, A., 1991. La formation des Grès du Luxembourg, au Lias inférieur: reconstitution dynamique du paléoenvironnement. Bulletin de la Société géologique de France, 162, 763-773. https://doi.org/10.2113/gssgfbull.162.4.763

Guillocheau, F., 1983. Les dépôts de tempêtes. Le modèle de l'Ordovicien moyen ouest-armoricain. Unpublished 3rd cycle thesis, Université de Bretagne Occidentale, Brest, France, 223 p.

Hallam, A., 1985. A review of Mesozoic climates. Journal of the Geological Society of London, 142, 433-445. https://doi.org/10.1144/ gsjgs. 142.3.0433

Hallam, A., 2001. A review of the broad pattern of Jurassic sea-level changes and their possible causes in the light of current knowledge. Palaeogeography, Palaeoclimatology, Palaeoecology, 167, 23-37. https://doi.org/10.1016/S0031-0182(00)00229-7.

Haq, B.U., Hardenbol, J. \& Vail, P.R., 1987. Chronology of fluctuating sea levels since the Triassic (250 million years ago to present). Science, 235, 1156-1167. https://doi.org/10.1126/science.235.4793.1156

Lucius, M., 1952. Manuel de la Géologie du Luxembourg: vue d'ensemble sur l'aire de sédimentation luxembourgeoise. Imprimerie de la Cour V. Buck, Luxembourg, 406 p.

Mabille, C. \& Boulvain, F. 2007. Sedimentology and magnetic susceptibility of the Upper Eifelian-Lower Givetian (Middle Devonian) in SW Belgium: insights into carbonate platform initiation. In Alvaro, J.J., Aretz, M., Boulvain, F., Munnecke, A., Vachard, D. \& Vennin, E. (eds), Palaeozoic Reefs and Bioaccumulations: Climatic and Evolutionary Controls. Geological Society, London, Special Publications, 275, 109-123.

McCabe, C. \& Elmore, R.D., 1989. The occurrence and origin of Late Paleozoic remagnetization in the sedimentary rocks of North America. Reviews of Geophysics, 27, 471-494. https://doi. org/10.1029/RG027i004p00471

Maubeuge, P.L., 1952. Quelques compléments sur l'âge et la faune de la "Marne sableuse de Hondelange" (Province de Luxembourg). Bulletin de la Société belge de Géologie, Paléontologie et Hydrologie, $61,210-214$

Maubeuge, P.L., 1954. Le Trias et le Jurassique du sud-est de la Belgique. In Fourmarier, P. (ed.), Prodrome d'une description géologique de la Belgique. Société géologique de Belgique, Liège, 385-416.

Maubeuge, P.L., 1963. Etudes stratigraphiques et paléontologiques sur la "Marne sableuse de Hondelange" (Lias inférieur et moyen) dans la province de Luxembourg. Avec étude des Eoderoceratidae lotharingiens et de deux formes du Lias moyen. Mémoires de 1'Académie royale de Belgique, Classe des Sciences, 34, 1-25.

Maubeuge, P.L., 1965. Contribution à la géologie de la Province de Luxembourg et du Grand-Duché de Luxembourg: le problème du "Grès de Luxembourg". Bulletin de la Société belge de Géologie, Paléontologie et Hydrologie, 74, 316-346.
Mertens, G., Spies, E.D. \& Teyssen, T., 1983. The Luxembourg sandstone formation (Lias), a tide-controlled deltaic deposit. Annales de la Société géologique de Belgique, 106, 103-109.

Michel, J., Boulvain, F., Philippo, S. \& Da Silva, A-C., 2010. Palaeoenvironmental study and small scale correlations using facies analysis and magnetic susceptibility of the Mid-Emsian (Himmelbaach quarry, Luxembourg). Geologica Belgica, 13, 447458.

Monteyne, R., 1959. La limite Hettangien-Sinemurien dans l'est du Luxembourg belge; l'âge des sables de Metzert. Bulletin de la Société belge de géologie, 68, 125-133.

Mouterde, R., Tintant, H., Allouc, J., Gabilly, J., Hanzo, M., Lefavrais, A. \& Rioult, M., 1980. Lias. In Mégien, C. \& Mégien, F. (eds), Synthèse géologique du Bassin de Paris: stratigraphie et paléogéographie. Mémoires du Bureau de Recherches géologiques et minières, 101, 75-123.

Muller, A., Parting, H. \& Thorez, J., 1973. Caractères sédimentologiques et minéralogiques des couches de passage du Trias au Lias sur la bordure nord-est du Bassin de Paris. Annales de la Société géologique de Belgique, 96, 671-707.

Plint, A.G. \& Nummedal, D. 2000. The falling stage systems tract: recognition and importance in sequence stratigraphic analysis. In Hunt, D. \& Gawthorpe, R.L. (eds), Sedimentary response to forced regressions. Geological Society, London, Special Publications, 172, 1-17. https://doi.org/10.1144/GSL.SP.2000.172.01.01

Pomar, L. \& Hallock, P., 2008. Carbonate factories: a conundrum in sedimentary geology. Earth-Science Reviews, 87, 134-169. https:// doi.org/10.1016/j.earscirev.2007.12.002

Posamentier, H.J., Jervey, M.T. \& Vail, P.R., 1988. Eustatic control on clastic deposition I: conceptual framework. In Wilgus, C.K. Hastings, B.S., Kendall, C.G., Posamentier, H.W., Ross, C.A. \& Van Wagoner, J.C. (eds), Sea-level change: an integrated approach. Society for Economic Paleontologists and Mineralogists Special Publications, 42, 109-124.

Purser, B.H., 1975. Sédimentation et diagenèse précoce des séries carbonatées du Jurassique moyen de Bourgogne. Unpublished PhD thesis, Université de Paris-Sud Orsay, France, 452 p.

Robin, C., Guillocheau, F. \& Gaulier J.M., 1996. Mesure des signaux eustatiques et tectoniques au sein de l'enregistrement sédimentaire d'un bassin intracratonique. Application au Lias du Bassin de Paris. Comptes Rendus de l'Académie des Sciences de Paris, Série II a, 322, 1079-1086.

Steininger, J., 1828. Essais d'une description géognostique du GrandDuché de Luxembourg. Imprimerie de l'Académie royale, Bruxelles, $88 \mathrm{p}$.

Tite, M. S. \& Linington, R. E., 1975. Effect of climate on the magnetic susceptibility of soils. Nature, 256, 565-566. https://doi. org/10.1038/256565a 0

Vail, P.R., Mitchum, R.M. Jr., Todd, R.G., Widmier, J.M., Thompson, S. III., Sangree, J.B., Bubb, J.N. \& Hatleilid, W.G., 1977. Seismic stratigraphy and global changes of sea level. In Payton, C.E. (ed.), Seismic Stratigraphy - Applications to Hydrocarbon Exploration. American Association of Petroleum Geologists Memoirs, 26, 49212.

Van den Bril, K. \& Swennen, R., 2008. Sedimentological control on carbonate cementation in the Luxembourg Sandstone Formation. Geologica Belgica, 12, 3-23.

Vecsei, A. \& Duringer, P., 2003. Sequence stratigraphy of Middle Triassic carbonates and terrigenous deposits (Muschelkalk and Lower Keuper) in the SW Germanic Basin: maximum flooding versus maximum depth in intracratonic basins. Sedimentary Geology, 160, 81-105. https://doi.org/10.1016/S0037-0738(02)00337-8

Waterlot, G., Beugnies, A. \& Bintz, J., 1973. Ardenne - Luxembourg. Masson, Paris, Guides géologiques régionaux, $206 \mathrm{p}$.

Wright, V.P., 1994. Paleosols in shallow marine carbonate sequences. Earth-Science Reviews, 35, 367-395. https://doi.org/10.1016/00128252(94)90002-7

Zegers, T.E., Dekkers, M.J. \& Baily, S., 2003. Late Carboniferous to Permian remagnetization of Devonian limestones in the Ardennes: role of temperature, fluids and deformation. Journal of Geophysical Research, 108/B7, 2357, 19 p. https://doi.org/10.1029/2002JB002213

Ziegler, P.A., 1990. Geological Atlas of Western and Central Europe, 2nd ed. Shell Internationale Petroleum Maatschappij B.V., The Hague, 239 p.

Manuscript received 23.11.2017, accepted in revised form 08.03.2018, available on line 24.05.2018. 